\title{
MAKNA DAN SIMBOL TARI KIAMAT \\ PADA MASYARAKAT KERATUAN DARAH PUTIH DI KABUPATEN LAMPUNG SELATAN
}

\author{
Marisa \\ Jurusan Tari Fakultas Seni Pertunjukan Institut Seni Indonesia Yogyakarta \\ Email: imarisa099@gmail.com
}

\begin{abstract}
RINGKASAN
Tari Kiamat merupakan satu tarian yang hidup dan berkembang pada masyarakat adat Keratuan Darah Putih di Desa Kuripan Kecamatan Penengahan Kabupaten Lampung Selatan di Provinsi Lampung. Tari Kiamat adalah tarian penutup dari ruwah atau syukuran tujuh hari tujuh malam perkawinan pihak Keratuan Darah Puth yang disebut Nuhot atau Nyambai. Upacara ini dilaksanakan bersamaan dengan pengukuhan adok atau gelar adat tertinggi yang merupakan satu bagian penting dalam upacara pernikahan pada Keratuan Darah Putih. Tari Kiamat memiliki fungsi sebagai penutup atau sebagai akhir segala proses rangkaian upacara, merupakan bentuk rasa syukur dan rasa terima kasih atas kerja sama para punggawa, penyimbang, dan masyarakat adat Keratuan Darah Putih di Desa Kuripan Kecamatan Penengahan Kabupaten Lampung Selatan dalam mendukung seluruh rangkaian acara. Pokok permasalahan penelitian ini adalah makna dan simbol Tari Kiamat pada masyarakat Keratuan Darah Putih, yang dipecahkan dengan teori Ferdinand De Saussure terkait petanda dan penanda yang merupakan kunci dalam pengungkapan analisis makna terhadap simbol-simbol yang ada pada Tari Kiamat. Makna-makna yang telah didapatkan nantinya akan dikaitkan dengan adanya relasi sistem kemasyarakatan pada masyarakat Keratuan Darah Putih. Hasil anlisis data dalam penemuan makna dari simbol-simbol pada Tari Kiamat menunjukkan relasi sistem kemasyarakatan Keratuan Darah Putih. Hal tersebut dikaitkan dengan kehidupan masyarakat Keratuan Darah Putih yang hidup dengan berpedoman pada Piil pesenggiri yang juga merupakan bagian dari pedoman kehidupan masyarakat Lampung. Seluruh keterkaitan tersebut diterangkan dalam bentuk penyajian Tari Kiamat yang disuguhkan sebagai tarian yang sakral karena hanya boleh ditarikan oleh keturunan atau atas seizin dari pihak Keratuan Darah Putih. Hal tersebut dibuktikan dengan adanya bentuk Tari Kiamat dalam acara ruwah perkawinan adat Keratuan Darah Putih yang umumnya hanya terjadi pada kurun waktu 20 - 30 tahun sekali.
\end{abstract}

Kata Kunci: Tari Kiamat, Keratuan Darah Putih, Lampung Selatan

\section{ABSTRACT}

Kiamat dance is one of the dances that lives and develops in the indigenous people of the White Blood Association in Kuripan Village, Penengahan District, South Lampung Regency in Lampung Province. Doomsday dance is a closing dance from Ruwah or Thanks giving for seven days and seven nights of marriage, the White Blood Association called Nuhot or Nyambai. This ceremony is held in conjunction with the inauguration of adok or the highest customary title which 
is an important part of the wedding ceremony at the White Blood Association. Kiamat dance has a function as a closing or as the end of all the process of a series of ceremonies. Kiamat Dance is a form of gratitude and gratitude for the cooperation of the retainer, balancer, and indigenous people of the White Blood Association in Kuripan Village. Penengahan Subdistrict, South Lampung Regency in supporting the whole series of events.

The main question of this research is the meaning and symbol of the Kiamat Dance in the White Blood Society. This problem can be solved through the use of theory by Ferdinand De Saussure regarding markers and markers which are key in the disclosure of meaning analysis of symbols that exist in Kiamat Dance. The meanings obtained will be presented with a community relations system in the White Blood Society.

The results of data analysis in the discovery of the meaning of the symbols on Doomsday Dance show the relation of the social system of the White Blood Unity. This is related to the lives of the people of the White Blood Society who live by referring to Piil Pesenggiri, which is also part of the life guidelines of Lampung people. All of these linkages are accepted in the form of presenting the Doomsday Dance which is presented as a sacred dance because it is only permitted for people who have permission from the White Blood Association. This is evidenced by the form of Doomsday Dance in the event of the traditional marriage ceremony for the White Blood Association which can be done once every 20-30 years.

Keywords: Kiamat Dance, White Blood Unity, South Lampung

\section{PENDAHULUAN}

Tari Kiamat adalah satu di antara beberapa tarian tradisional Lampung. Tari tradisional daerah Lampung berkembang bersama tradisi suku Lampung dalam berbagai ragamnya yang berorientasi pada nilai adat istiadat daerah Lampung. Perwujudannya terdapat dalam upacara-upacara tertentu. Tari Kiamat termasuk tari yang lahir di masyarakat Lampung beradat Saibatin (peminggir) yang berada di daerah Kabupaten Lampung Selatan. Masyarakat Lampung Selatan merupakan golongan masyarakat beradat Saibatin atau peminggir yang memiliki enam marga yaitu Marga Ratu (Desa Negeri Pandan, Desa Kekiling, Desa Kuripan, Desa Taman Baru,
Desa Kelau, Desa Ruang Tengah, dan Desa Tetaan), Marga Dantaran (Desa Penengahan, Desa Pisang, Desa Suka Baru, Desa Gayam), Marga Way Urang (Desa Way Urang dan kota Kalianda), Marga Rajabasa (Timur Gunung Rajabasa), Marga Legun, dan Marga Ketibung. Tari Kiamat hanya ada dalam adat Marga Ratu keturunan Ratu Darah Putih.

Dua golongan suku Lampung yakni pepadun dan saibatin memiliki persamaan yakni keterlibatan sistem adat masyarakat dalam sebuah upacara pernikahan, dan bagaimana kedudukan seseorang di dalam lembaga adat dapat dilihat. Kedudukan 
seseorang dilihat dalam lembaga adat ditentukan berdasarkan sistem patrilineal yaitu seorang pemimpin ialah laki-laki tertua dari keturunan tertua. Perbedaan kedua golongan ini adalah pada masyarakat pepadun, dimungkinkan baginya untuk menaikkan kedudukan sebagai kepala adat marga dengan prasyarat adat. Sedangkan pada masyarakat peminggir, kesempatan untuk menempati kedudukan sebagai kepala adat hanya sampai sebatas kepala adat kampung (tiyuh atau pekon atau anek) dengan syarat telah ada pengikutnya. Bagi masyarakat Lampung Saibatin pemimpin adat tertinggi hanya diperoleh berdasarkan keturunan yang selalu dikaitkan dengan aturan-aturan adat yang berlaku secara turun-temurun. ${ }^{1}$

Persamaan lain adalah pemahaman akan fungsi-fungsi seni di dalam masyarakat yang memberikan kejelasan bahwa setiap masyarakat membangun pemahaman sendiri akan dunia seni mereka. Pada pemahaman masyarakat Lampung apa yang disebut 'seni' umumnya selalu terkait dengan sebuah 'peristiwa adat', bahkan merupakan peristiwa adat itu sendiri. ${ }^{2}$

${ }^{1}$ Rina Martiara. 2014. Cangget: Identitas Kultural Lampung Sebagai Bagian Dari Keragaman Budaya Indonesia . Yogyakarta: ISI Yogyakarta, 41.

${ }^{2}$ Rina Martiara. 2014. Nilai dan Norma Budaya Lampung: dalam Sudut Pandang Strukturalisme. Yogyakarta: ISI Yogyakarta, 5.
Peristiwa tari yang ada pada masyarakat Keratuan Darah Putih tak terlepas dari upacara adat. Tari Kiamat sebagai salah satu bagian dari rangkaian upacara ruwah atau khuah yang berarti syukuran yang hadir di dalam upacara perkawinan adat.

“. . .Keratuan Darah Putih memiliki berbagai macam bentuk upacara terkait ritual daur hidup. Setiap memasuki atau melangkah ke jenjang kehidupan yang berbeda, akan dilakukan upacara. Upacara itu disebut dengan Ruwah atau syukuran. Adat istiadat dalam upacara mereka tidak lepas dari seni tari.Upacara ruwah dalam pernikahan keturunan Keratuan Darah Putih terdapat kesenian tari yaitu tari tuping, tari mamandapan dan rudat. Pada upacara yang disebut nuhot atau nyambai ditambahkan dengan tari Kiamat untuk mengakhiri segala proses acara... ...3

Pada awal mula kehadirannya, tari Kiamat hanya boleh ditarikan oleh keturunan Keratuan Darah Putih. Hal ini menyebabkan kurun waktu dipentaskannya Tari Kiamat hanya terjadi 20-30 tahun sekali dalam upacara perkawinan adat Keratuan Darah Putih. Penari Tari Kiamat berjumlah lima orang yang terdiri dari keturunan marga Ratu dan empat keturunan marga Pangeran. Tempat pertunjukan Tari Kiamat di Lamban balak atau rumah adat Keratuan.Waktu pementasan Tari Kiamat yaitu sebelum subuh atau sekitar pukul 04.30. Kostum yang dikenakan oleh lima penari merupakan kostum pengantin wanita

\footnotetext{
${ }^{3}$ Wawancara dengan bapak Budiman Yakub di kediamannya Kuripan Penengahan, Lampung Selatan pada tanggal 16 Januari 2019.
} 


\section{JOGED}

ISSN: $1858-3989$
MAKNA DAN SIMBOL TARI KIAMAT PADA MASYARAKAT KERATUAN DARAH PUTIH DI KABUPATEN LAMPUNG SELATAN masyarakat Keratuan Darah Putih. Kostum yang paling spesifik adalah aksesoris kepala yang disebut Sigekh atau Siger. Sigekh yang ada pada masyarakat Keratuan Darah Putih, memiliki tujuh lekuk (Sigekh Lekuk Pitu) dengan hiasan tambahan di atas siger sebagai ciri khas yang disebut Kepundul. Riasan wajah yang digunakan penari Tari Kiamat ialah rias korektif. Tari Kiamat menggunakan properti tari yaitu kipas berwarna putih yang rangkanya terbuat dari bambu. Kipas yang digunakan oleh penari masing-masing satu pasang atau dua buah. Iringan tabuhan yang digunakan di dalam Tari Kiamat adalah tabuhan Arus dan Ganjor.

Tari Kiamat merupakan satu tarian yang hidup dan berkembang pada masyarakat adat Keratuan Darah Putih di Desa Kuripan Kecamatan Penengahan Kabupaten Lampung Selatan di Provinsi Lampung. Tari Kiamat adalah tarian penutup dari ruwah atau syukuran tujuh hari tujuh malam perkawinan pihak Keratuan Darah Putih yang disebut Nuhot atau Nyambai. Upacara ini dilaksanakan bersamaan dengan pengukuhan adok atau gelar adat tertinggi yang merupakan satu bagian penting dalam upacara pernikahan pada Keratuan Darah Putih. Tari Kiamat memiliki fungsi sebagai penutup atau sebagai akhir segala proses rangkaian upacara, merupakan bentuk rasa syukur dan rasa terima kasih atas kerja sama para punggawa, penyimbang, dan masyarakat adat Keratuan Darah Putih di Desa Kuripan Kecamatan Penengahan Kabupaten Lampung Selatan dalam mendukung seluruh rangkaian acara.

Kata Kiamat secara harfiah diserap dari bahasa arab Yaum al Qiyamah yang terdiri dari tiga suku kata, yaitu: Yaum (berarti hari, masa atau periode); Qiyam (berarti tegak, bangkit, berdiri), dan 'Ummah (berarti umat, bangsa, kaum). Dari ketiga suku kata tersebut Yaum alQiyamah secara denotatif berarti "Hari Kebangkitan Umat”, Pengertian Kiamat di sini bukanlah sebagai "Hari Kiamat" yang dalam bahasa Arab adalah "As-saa'ah" (berarti kehancuran alam semesta beserta isinya). Yaumul Qiyamah sama halnya dengan Yawm ad-Din yang artinya suatu periode (masa) di mana akan terjadi kebangkitan sebuah komunitas umat manusia yang hidup berdasarkan agama Allah (dinullah) ${ }^{4}$

Keterangan di atas menjelaskan bahwa Tari Kiamat pada masyarakat Keratuan Darah Putih bukanlah sebagai tari "kehancuran alam semesta beserta isinya" melainkan sebagai tarian yang memiliki makna keikhlasan, kebaikan atas semua kesalahan yang pernah dilakukan. Sebagaimana keterangan yang dijelaskan di dalam Al-Quran pada surah AzZumar ayat 68 dengan arti: "Dan sangkakala

\section{${ }^{4}$ Sumber:}

https://id.m.wikipedia.org/wiki/Yaumul_Qiyamah, diunduh pada tanggal 27 Maret 2019. 
pun ditiup maka matilah semua (makhluk) yang di langit dan di bumi kecuali mereka yang dikehendaki Allah. Kemudian ditiup sekali lagi sangkakala itu maka seketika itu mereka bangun (dari kuburnya) menunggu (keputusan Allah)".

Seiring dengan perkembangan zaman, tari Kiamat mengalami pergeseran. Beberapa perubahan itu antara lain, jika pada masa lalu yang boleh menarikan tari Kiamat hanya keturunan Keratuan Darah Puth saja, saat ini pihak luar telah diperbolehkan menari, namun dengan syarat mendapat izin dari pihak keluarga Keratuan. Fungsi tari Kiamat sebagai akhir dari upacara perkawinan adat keturunan Keratuan (dalam upacara ruwah) masih dipertahankan, namun bila dipentaskan di luar acara ruwah, maka fungsinya hanya sebagai hiburan.

Keputusan tersebut tidak menjauhkan Tari Kiamat sebagai kajian-kajian budaya yang terdapat pada masyarakat Keratuan Darah Putih. Kajian budaya di dalam tari didapatkan ketika tari dipandang sebagai perilaku manusia yang memiliki fungsi sosial. Kebudayaan tari adalah seluruh aspek yang menyeluruh -baik secara diakronik maupun sinkronik--, di dalam kehidupan manusia dan bukan hanya sebagai pertunjukan semata. ${ }^{5}$

${ }^{5}$ Rina Martiara. 2012. Nilai dan Norma Budaya Lampung dalam Sudut Pandang Strukturalisme. Institut Seni Indonesia Yogyakarta: Yogyakarta, 4.
Mencatat fungsi-fungsi tari di dalam masyarakat dapat menentukan pentingnya tari dalam kebudayaan. Mengamati secara menyeluruh apa yang ada di dalam tari dapat mengukur pentingnya tari dalam kelompok atau masyarakat. Hal ini yang akan dilakukan dalam pencarian makna dan simbol Tari Kiamat pada masyarakat Keratuan Darah Putih.

Simbol adalah obyek atau peristiwa apapun yang menunjuk pada sesuatu, yang melibatkan tiga unsur, yaitu simbol itu sendiri, satu rujukan atau lebih, dan hubungan antara simbol dengan rujukan. Hubungan antara sebuah simbol dengan sebuah rujukan adalah unsur ketiga dalam makna. Hubungan itu merupakan hubungan yang berubah-ubah yang di dalamnya rujukan disandikan dalam simbol itu. Setidak-tidaknya, makna melibatkan simbol dan rujukan, yang disebut makna referensial. Makna referensial hanya mulai menggores permukaan makna yang disandikan dalam simbol-simbol yang digunakan oleh masyarakat. ${ }^{6}$

Analisis makna terhadap simbol atau tanda yang ada dalam Tari Kiamat akan menggunakan kajian semiotika sebagai pendekatan teoretis yang berorientasi pada kode (sistem) dan pesan (tanda-tanda dan maknanya) tanpa mengabaikan konteks dan pihak pembaca. Hal tersebut dapat dilihat di

\footnotetext{
${ }^{6}$ James P. Spradley. 1997. Metode Etnografi.
} Yogyakarta: Tiara Wacana Yogyakarta,`122 
mana posisi semiotika sebagai sebuah pendekatan yang dapat dijabarkan dalam pengungkapan makna atas simbol atau tanda. Menurut Saussure, tanda mempunyai dua entitas, yaitu signifier dan signified atau wahana 'tanda' dan 'makna' atau 'penanda' dan 'petanda'. Pernyataan tersebut mendukung dalam analisis makna dan simbol melalui 'penanda' dan 'petanda' yang ada di dalam Tari Kiamat. ${ }^{7}$ Tari Kiamat sebagai ekspresi seni adalah simbol yang digunakan sebagai rujukan oleh masyarakat, sehingga setiap simbol yang tercermin dalam setiap bentuk penyajian Tari Kiamat tidak dapat dipisahkan dari identitas budaya atau ciri-ciri sebuah budaya.

Makna dan simbol tari Kiamat merupakan satu kesatuan sistem budaya yang terkait dengan kepercayaan dan sistem kekerabatan masyarakat adat Keratuan Darah Putih. Hal tersebut yakni tatanan berpikir (cara berpikir, orientasi berpikir); perasaan (cara perasaan dan orientasi perasaan), dan cara bertindak (motivasi tindakan atau orientasi tindakan). ${ }^{8}$ Dengan demikian, analisis makna dan simbol tari Kiamat terkait dengan unsur dan nilai dalam fungsi sosial, pranata sosial, dan struktur sosial dari masyarakat adat Keratuan

\footnotetext{
${ }^{7}$ Panuti Sudjiman dan Aart Van Zoest. 1992 Serba-Serbi Semiotika. Jakarta: PT Gramedia Pustaka Utama, 42.

${ }^{8}$ Alo Liliweri. 2007. Makna Budaya dalam Komunikasi Antarbudaya. Yogyakarta: LKiS, 72.
}

Darah Putih. Analisis makna dan simbol akan dijabarkan melalui tanda/simbol yang terdapat pada bentuk penyajian dalam Tari Kiamat pada masyarakat Keratuan Darah Putih.

\section{PEMBAHASAN}

\section{A. Fungsi Tari Kiamat Dalam Perkawinan Nuhot dan Nyambai}

Tari Kiamat adalah tarian penutup dari ruwah atau syukuran perkawinan pihak Keratuan Darah Putih yang disebut Nuhot dan Nyambai. Rangkain upacara perkawinan ini hanya akan terjadi terhadap perkawinan keluarga Keratuan atau dapat dilihat dari keturunan anak laki-laki pertama pihak Keratuan yang mampu melaksanan upacara nuhot dan nyambai. Perbedaan nuhot dan nyambai adalah dari segi material atau biaya yang dikeluarkan. Nuhot merupakan rangkaian upacara perkawinan yang biaya keseluruhannya ditanggung pihak keluarga Keratuan yang memiliki hajat. Sedangkan nyambai, biaya keseluruhannya didapatkan dari gotong royong masyarakat Keratuan Darah Putih.

\section{Upacara nuhot ataupun nyambai} dilaksanakan bersamaan dengan pengukuhan adok atau gelar adat tertinggi yang merupakan satu bagian penting dalam upacara perkawinan nuhot dan nyambai pada Keratuan Darah Putih. Pemberian/pengukuhan gelar pada Keratuan Darah Putih menggunakan budaya 
penamongan. Kata penamongan berasal dari kata tamong yang berarti kakek/nenek, dengan maksud gelar yang didapat berasal dari kakek kepada anak laki-laki yang pertama.

Pada masyarakat Keratuan Darah Putih yang beradat saibatin atau peminggir, kesempatan menempati kedudukan sebagai kepala adat hanya sebatas kepala adat kampung (tiyuh atau pekon atau anek) dengan syarat telah ada pengikutnya (penduduk), sedangkan kepala adat tingkat marga (marga genealogis) secara turun-temurun tidak pernah bertambah. Kekuasaan adat tetap dipegang oleh kepala adat yang lama. Upacara adat dan pakaian adat tidak dapat dialihkan ke warga lain. Kedudukan warga adat berdasar pada prinsip 'berjenjang naik bertangga turun', yang di bawah tetap di bawah dan yang di atas tetap berada di atas. ${ }^{9}$ Hal tersebut menyebabkan kurun waktu dipentaskannya Tari Kiamat hanya terjadi 20-30 tahun sekali dalam upacara perkawinan adat Keratuan Darah Putih.

Perkawinan di dalam masyarakat Lampung, baik adat saibatin ataupun pepadun dilakukan dengan tata cara aturan agama Islam. Sedangkan sistem adat pada pepadun memiliki rangkaian upacara yang disebut cangget, dan

${ }^{9}$ Rina Martiara. 2014. Cangget: Identitas Kultural Lampung Sebagai Bagian Dari Keragama Budaya Indonesia .Yogyakarta: BP ISI Yogyakarta, 41. saibatin beberapa di antaranya adalah nayuh, khuah lamban, pekekh, nuhot, dan nyambai. Masyarakat Keratuan Darah termasuk dalam sistem adat saibatin, sehingga rangkaian upacara perkawinan dapat dilihat berdasarkan golongan adat tertinggi mulai dari kalangan biasa yaitu khuah lamban dan pekekh, sampai yang hanya boleh dilakukan dari pihak Keratuan Darah Putih yaitu nuhot dan nyambai.

Nuhot dan nyambai pada masyarakat Keratuan Darah Putih menciptakan status baru di dalam keadatan. Pemberian gelar yang telah terlaksana menandakan perubahan status dengan naiknya tahta seseorang. Pemberian gelar di dalam rangkaian upacara perkawina nuhot dan nyambai hanya terjadi oleh pihak keturunan anak laki-laki pertama Keratuan Darah Putih. Upacara tersebut mengesahkan lahirnya pemimpin baru di dalam Keratuan. Keseluruhan rangkaian upacara akan dikatakan selesai dan sah dengan ditandai hadirnya Tari Kiamat sebagai penutup ruwah/syukuran upacara perkawinan.

Kehadiran Tari Kiamat di dalam upacara perkawinan nuhot dan nyambai menyimbolkan makna-makna adanya relasi secara sistem budaya. Sistem budaya yang ada pada masyarakat Lampung adalah pi-il pasenggiri yaitu rasa harga diri yang tinggi. Bagi masyarakat Lampung, tolak ukur keberhasilan adalah pi-il pasenggiri. Rumusan 
falsafah pi-il pasenggiri dalam masyarakat Lampung terdapat dua sumber bahasa yang berbeda yakni dari adat saibatin dan pepadun namun memiliki arti yang sama. Berikut falsafah pi-il pasenggiri bagi adat saibatin dan pepadun beserta terjemahannya:

\begin{tabular}{|l|l|l|l|}
\hline $\begin{array}{l}\mathbf{N} \\
\mathbf{0}\end{array}$ & $\begin{array}{l}\text { Adat } \\
\text { saibatin }\end{array}$ & $\begin{array}{l}\text { Adat } \\
\text { pepadu } \\
\boldsymbol{n}\end{array}$ & $\begin{array}{l}\text { Arti/terjemaha } \\
\mathbf{n}\end{array}$ \\
\hline $\begin{array}{l}\text { Bupi-il } \\
\text { bupasenggir } \\
\text { i }\end{array}$ & $\begin{array}{l}\text { Pi-il } \\
\text { pasenggir } \\
i\end{array}$ & Prinsip/harga diri \\
$\begin{array}{l}\text { Bupudak } \\
\text { waya }\end{array}$ & $\begin{array}{l}\text { Nemui } \\
\text { nyimah } \\
\text { Khopkhama } \\
\text { delom } \\
\text { bekekhja }\end{array}$ & $\begin{array}{l}\text { Juluk } \\
\text { adek }\end{array}$ & $\begin{array}{l}\text { Kerja } \\
\text { keras/gelar/prestise }\end{array}$ \\
\hline $\begin{array}{l}\text { Tetangah } \\
\text { tetanggah }\end{array}$ & $\begin{array}{l}\text { Nengah } \\
\text { nyappur }\end{array}$ & Pandai bergaul \\
\hline $\begin{array}{l}\text { Khepot } \\
\text { delom } \\
\text { mupakat }\end{array}$ & $\begin{array}{l}\text { Sakai } \\
\text { sambayan }\end{array}$ & $\begin{array}{l}\text { Kerjasama/tolong } \\
\text { menolong }\end{array}$ \\
\hline
\end{tabular}

Dari falsafah pi-il pasenggiri di atas, dapat dilihat relasi hadirnya Tari Kiamat di dalam perkawinan nuhot dan nyambai. Seluruh rangkaian upacara perkawinan nuhot dan nyambai menerapkan falsafah pi-il pasenggiri di antaranya:

a. Bupi-il bupasenggiri yang memiliki arti prinsip/harga diri orang Lampung. Ketika upacara perkawinan nuhot dan nyambai, seluruh masyarakat yang terlibat di dalamnya akan berperilaku baik. Hal tersebut terlihat dari bagaimana tata cara perilaku masyarakat yang saling menghormati satu sama lain terlebih kepada pihak keluarga adat Keratuan tertinggi. Masyarakat adat saibatin pada Keratuan Darah Putih akan mengenakan pakaian sesuai aturan adat yang dapat menunjukkan tingginya/tingkatan gelar kedudukan seseorang. Tata cara mengenakan pakaian adat yang dapat menunjukkan satu kedudukan dalam upacara ini satu contohnya terlihat di dalam pakaian yang dikenakan penari pada Tari Kiamat. Perbedaan jumlah gelang dan kalung serta seorang Ratu yang menaiki pahar/talam menunjukkan adanya perbedaan tingkatan dalam suatu Keratuan. Dalam hal ini bupi-il bupasenggiri sangat diperlukan dalam menjalankan kehidupan bermasyarakat untuk selalu menghargai dan berprinsip dalam menjalankan aturanaturan yang telah ditentukan oleh ketua atau pimpinan adat. Aturanaturan yang berlaku tersebut diharapkan dapat terus dijunjung tinggi dan dipertahankan.

b. Bupudak waya yang memiliki arti bermuka manis sama halnya dengan bermasyarakat, dan sopan santun. Satu kebutuhan manusia adalah membutuhkan satu sama lain. Masyarakat saibatin biasanya akan saling mengunjungi kerabat secara bergantian. Upacara perkawinan nuhot dan nyambai menjadi satu tempat bagi masyarakat Keratuan Darah Putih untuk saling berinteraksi, mempererat tali silaturahmi, bermusyawarah agar rangkaian upacara perkawinan nuhot maupun nyambai dapat berjalan dengan lancar.

c. Khopkhama delom bekekhja yang memiliki arti bekerja keras untuk mendapat suatu hasil yang memuaskan. Nilai kerja keras di dalam upacara nuhot dan nyambai sangat dibutuhkan dalam terlaksananya seluruh rangkaian upacara perkawinan. Kerja keras yang 
dilakukan oleh masyarakat Keratuan Darah Putih terlihat dari selesainya seluruh rangkaian upacara yang ditandai dengan adanya Tari Kiamat.

d. Tetangah tetanggah yang memiliki arti pandai bergaul. Kerja sama dalam terlaksananya rangkaian upacara tidak akan terjalin jika tidak ada komunikasi dan saling sapa pada setiap individu. Rangkaian upacara perkawinan akan berjalan dengan lancar karena masyarakat yang dengan senang hati dalam menjalin kerja sama.

e. Khepot delom mupakat yang memiliki arti gotong royong atau tolong menolong. Upacara perkawinan nuhot dan nyambai merupakan satu simbol adanya hubungan kemasyarakatan berdasarkan asas kekeluargaan yang saling tolong menolong. Hal tersebut terlihat dengan adanya pembagian tugas yang dilakukan oleh pemimpin atau ketua adat berdasarkan kategori usia. Pembagian tugas bertujuan untuk mempermudah pekerjaan sehingga pekerjaan lebih cepat selesai.

\section{B. Makna dan Simbol Gerak Tari Kiamat}

Simbol-simbol gerak dalam koreografi adalah satu dan padu; simbol-simbol itu tidak hanya menyampaikan nilai, makna untuk dimengerti, tetapi lebih kepada "pesan" untuk diresapkan sehingga penonton dapat tersentuh secara mendalam dan intensif. ${ }^{10}$ Gerak yang ada di dalam Tari Kiamat yakni lapah tebeng, ukel, sembah, dan kenuy ngelayang. Lapah tebeng (pn) dalam Tari Kiamat memiliki makna keselarasan dalam hidup bermasyarakat, tenang namun pasti dalam menghadapi masalah (pt). Gerak ukel tidak memiliki makna khusus dalam Tari Kiamat, namun

\footnotetext{
${ }^{10}$ Y. Sumandiyo Hadi. 2014. Koreografi
} Bentuk-Teknik-Isi. Yogyakarta: Cipta Media, 66. gerak ini menambah estetika gerakan pada saat membawa kipas pada tangan kanan dan kiri. Dua gerak lainnya yang memiliki makna di dalam Tari Kiamat yaitu motif gerak sembah (pn) dan kenuy ngelayang (pn). Motif gerak sembah (pn) bagi masyarakat dianggap sebagai simbol penghormatan dan merupakan wujud ekspresi yang dapat diartikan sebagai ungkapan rasa hormat, menghargai, dan terima kasih sebagai simbol penghormatan (pt).

Gerak tangan lainnya adalah kenuy ngelayang (pn). Kenuy adalah elang, sedangkan ngelayang adalah saat ketika sang elang terbang tanpa mengepakkan sayap. Pada masyarakat Dayak, burung enggang (pn) dihubungkan secara mitologis dengan penciptaan manusia serta dimuliakan sebagai simbol dunia atas (pt). ${ }^{11}$ Pendapat tersebut juga diyakini oleh masyarakat Lampung yakni burung elang (pn), sama halnya dengan burung enggang yang merupakan binatang yang hidup di udara sebagai simbol dunia atas dan dikagumi oleh masyarakat Keratuan Darah Putih (pt). Burung elang divisualisasikan dalam beberapa bentuk aksesesoris atau gelang dan lainnya tarian khas Lampung. Beberapa Negara mempercayai burung elang sebagai lambang dalam pemerintahan yang disebutkan langsung dalam sejarah catatan Alkitab. Diketahui elang adalah burung yang mampu terbang paling tinggi di dunia. Seekor elang mampu terbang dengan terpaan angin yang sangat kencang. Binatang tersebut mampu mencapai umur 70 dengan membuat suatu keputusan yang sangat berat pada umurnya yang ke-40 untuk memilih antara menunggu kematian atau mengalami proses transformasi yang sangat menyakitkan selama 150 hari.

Kepercayaan terhadap burung elang (pn) itulah yang memaknai Tari Kiamat dalam geraknya sebagai suatu simbol yaitu memimpin suatu pemerintahan dengan

${ }^{11}$ Rina Martiara. 2014. Cangget: Identitas Kultural Lampung Sebagai Bagian Dari Keragama Budaya Indonesia . Yogyakarta: BP ISI Yogyakarta, 168. 
bijaksana, mampu melindungi dengan kekuatan yang berasal dari kerjasama pemerintahan masyarakat Keratuan Darah Putih. Kemampuan yang dimiliki seekor burung elang terhadap daya pengamatan dan penglihatannya yang jauh mampu memaknai sebagai simbol dalam memimpin ke arah yang lebih baik ke depannya dalam suatu pemerintahan pada Keratuan Darah Putih (pt).

\section{Makna dan Simbol Jumlah Penari Tari Kiamat}

Penari atau pelaku dalam Tari Kiamat diharuskan gadis (muli) (pn). Gadis (muli) dipilih sebagai penari Tari Kiamat, dapat dikaitkan dengan wanita ataupun perempuan yang diagungkan, yang harus dijaga sebagaimana adanya Cangget dan Liyom yang merupakan rasa malu, dunia perempuan, yang harus dijaga dan dipertahankan oleh semua orang Lampung (pt). Lima penari tersebut yang terdiri dari satu keturunan Keratuan Darah Putih dan empat keturunan Pangeran.

Penari Tari Kiamat yang berjumlah lima (pn) orang merupakan wujud bentuk yang menekankan pada pengenalan status sosial yang menggambarkan tingkatan silsilah keluarga atau sistem kekerabatan Keratuan Darah Putih (pt). Jumlah penari yang terbilang ganjil (pn) merupakan simbol yang memiliki makna dalam suatu masyarakat terdapat seseorang yang memimpin (pt). Lima dalam masyarakat Lampung mengaitkan dengan lima kerajaan/keratuan yang dahulu berkuasa di Lampung (pt). Kelima keratuan tersebut adalah Keratuan Ratu di puncak, Keratuan Ratu di Belau, Keratuan Ratu di Pugung, Keratuan Ratu di pemanggilan, dan Keratuan Ratu Darah Putih.

\section{Makna dan Simbol Iringan Tari Kiamat}

Tabuhan atau iringan Tari Kiamat biasa dikenal dengan istilah lambat (Ganjor) (pn) dan cepat (Arus) (pn). Tabuhan tari ini termasuk dalam tabuh tari, berfungsi untuk mengiringi tari adat. Fungsinya sebagai pengiring tari adalah pemberi irama dan membantu mempertegas ekspresi gerak. ${ }^{12}$ Pola irama dalam iringan Tari Kiamat tenang dan cenderung monoton dari awal hingga akhir.

Iringan musik dalam suatu tarian dapat menyimbolkan keadaan kebudayaan masyarakat. Kebudayaan masyarakat dapat diukur sejauh mana tingkat kebudayaan masyarakat tersebut. Masyarakat Keratuan Darah Putih merupapakan salah satu masyarakat yang memiliki kebudayaan yang maju dan berkembang dilihat dari sistem kemasyarakatan yang ada pada masyarakat Keratuan hingga sampai saat ini. Iringan musik Tari Kiamat selain membawa suasana dalam tarian, juga sebagai tolak ukur kebiasaan dan norma-norma yang berlaku dalam masyarakat Keratuan Darah Putih yang seimbang (pt).

\section{E. Makna dan Simbol Pola Lantai Tari Kiamat}

Pola lantai dalam Tari Kiamat mengerucut membentuk huruf "V" (pn) dengan penari paling depan memimpin penari lainnya yang di belakang dengan menaiki talam bekukut atau talam berkaki. Hal tersebut menyimbolkan kepemimpinan yang berada satu tingkat lebih tinggi namun tetap mengayomi dalam masyarakat Keratuan Darah Putih (pt).

\section{F. Makna dan Simbol Rias dan Busana Tari Kiamat}

Rias korektif yang dipakai dalam Tari Kiamat memberikan tanda kesederhanaan. Kesederhanaan dipancarkan oleh seorang gadis (muli) namun tetap anggun dan menjadi sosok yang wajib dilindungi dan dijaga. Busana yang dikenakan memiliki spesifikasi makna pada simbol-simbol yang ada pada setiap satu per satu dari keseluruhan kostum atau busana Tari Kiamat. Perlengkapan

${ }^{12}$ Rina Martiara. 2014. Cangget: Identitas Kultural Lampung Sebagai Bagian Dari Keragama Budaya Indonesia . Yogyakarta: ISI Yogyakarta, 166. 
kostum dalam Tari Kiamat yang memiliki makna tersendiri yaitu:

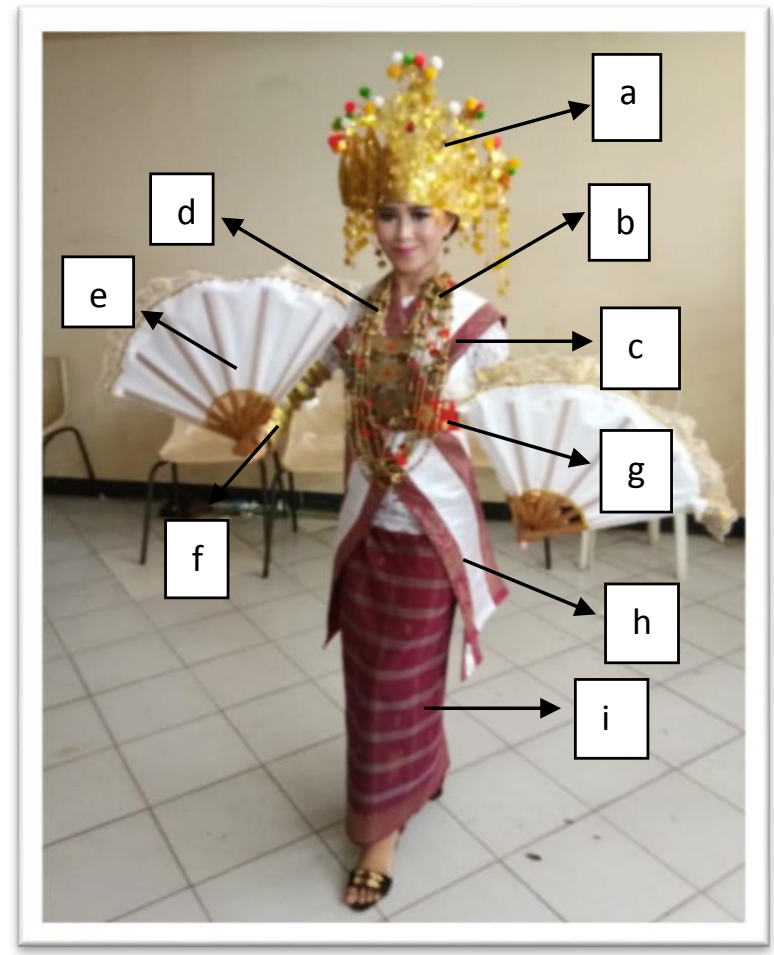

Gambar 17: Penari Tari Kiamat dengan rias dan busana.

(Dok: Koleksi pribadi Sanggar Intan Kuripan, Marisa, 2018)

Keterangan:
a. Sigekh/siger.
b. Kalung papan jajar.
c. Pending.
d. Kalung buah jukum.
e. Poperti kipas putih
f. Gelang kano.
g. Sesapur/baju kurung.
h. Selendang/jung khelok.
i. Kain songket/jung sakhat.

\section{a. Siger (sigekh)}

Siger (pn) yang dikenakan di dalam Tari Kiamat adalah siger ciri khas suku Saibatin. Berbeda dengan siger suku Pepadun yang memiliki ruji berlekuk Sembilan dan menandakan Sembilan sungai di Lampung, siger suku Saibatin memiliki tujuh lekuk/pucuk ruji (sigokh lekuk pitu) (pn).
Tujuh pucuk tersebut melambangkan tujuh marga yang dahulu bernaung di dalam Keratuan (pt). Tujuh marga tersebut adalah:

1. Marga Ratu.

2. Marga Dantaran.

3. Marga Legun.

4. Marga Rajabasa.

5. Marga Ketibung.

6. Marga Sekampung Udik.

7. Marga Sekampung Ilir.

Siger yang dipakai memiliki aksesoris tambahan sebagai ciri khas suku saibatin yang ada di Kabupaten Lampung Selatan yang disebut kepundul. Kata "kepundul" yang berarti bunga petai (pn) sebagai simbol tumbuhan yang banyak hidup di lingkungan masyarakat Kabupaten Lampung Selatan adalah tumbuhan petai dan perpaduan warna pada kepundul melambangkan keberagaman masyarakat namun tetap satu di dalam kemasyarakatan Keratuan Darah Putih (pt).

\section{b. Kain songket/jung sakhat}

Masyarakat saibatin daerah Kabupaten Lampung Selatan menggunakan kain songket atau jung sakhat dalam setiap acara adat atau acara tertentu. Hal tersebut merupakan satu ciri khas bagi masyarakat saibatin Kabupaten Lampung Selatan.

Kain songket ini digunakan sebagai kain penari pada gawi adat.Warna emas (pn) yang ada dalam kain songket ini melambangkan kemakmuran, kemewahan, kesuksesan, kemenangan, sifat aktif dan dinamis. Sama halnya dengan kepemimpinan dalam masyarakat Keratuan Darah Putih. Kepemimpinan yang bersifat dinamis mampu mengayomi dan memimpin masyarakat ke arah yang lebih baik (pt). Warna merah (pn) melambangkan keberanian, inspirasi, kehangatan, dan kekuatan. Hal tersebut 
menjadi satu simbol dalam sistem kemasyarakan yang ada pada Keratuan Darah Putih (pt). Kepemimpinan yang baik dalam pemerintahan Keratuan Darah Putih (pt) dapat dilihat dalam pola garis horizontal (pn) yang terdapat pada kain songket/jung sakhat.

\section{c. Sesapur dan Selendang Putih}

Sesapur adalah baju kurung atau baju yang dikenakan sebagai baju atasan penari. Sesapur dan selendang berwarna putih (pn) melambangkan kesucian, kemurnian, kebaikan. Warna putih dapat memberi kesan makna keterbukaan dan kebebasan dalam suatu kepemimpinan dalam masyarakat Keratuan Darah Putih (pt).

\section{d. Gelang Kano}

Gelang kano menyerupai bentuk ban. Gelang ini dikenakan pada lengan kiri dan kanan. Tari Kiamat memiliki satu ciri khas pada jumlah pemakaian yang dikenakan oleh penari. Penari yang mewakili keturunan Keratuan Darah Putih (pt) mengenakan Gelang Kano berjumlah dua belas pasang (pn). Sembilan pasang (pn) dikenakan oleh penari yang mewakili keturunan Pangeran (pt) di bawah keturunan Keratuan Darah Putih. Angka dua belas (pn) dianggap nilai paling tinggi dalam masyarakat Keratuan Darah Putih (pt).

\section{e. Kalung Papan Jajar}

Kalung Papan Jajar adalah kalung dengan gantungan tiga lempengan siger kecil atau perahu (pn) yang menjadi lambang kehidupan baru (pt).

\section{f. Kalung Buah Jukum}

Kalung Buah Jukum (pn) adalah kalung yang menyerupai buah jukum yang dirangkai sebagai simbolis keturunan (pt). Jumlah pemakaian kalung Buah Jukum sama dengan ketentuan pemakaian pada Gelang Kano. Dua belas (pn) untuk yang mewakili keturunan Keratuan Darah Putih (pt) dan sembilan (pn) untuk yang mewakili keturunan Pangeran (pt).

\section{G. Makna dan Simbol Properti Tari Kiamat}

Tari Kiamat memakai dua properti yaitu kipas putih dan talam bekukut (berkaki). Kipas putih (pn) ini sebagai simbol Keratuan Darah Putih akan keseimbangan dan kesucian (pt). Keseimbangan (pt) dilihat dari kipas berwarna putih (pn) yang menjadi objek dalam gerak keseimbangan tangan dengan arah hadap kanan dan kiri. Kesucian, kebebasan, dan keterbukaan dilihat dari simbol warna putih yang ada pada kipas tersebut. Talam berkaki yang dibuat dari tembaga, perak atau gangsa. Talam berkaki (pn) atau yang biasa disebut Pahar (pn), dulunya ialah merupakan tempat materi adat, makanan, atau peralatan dalam acara adat istiadat (pt).

Dalam kalangan Dayak zaman dulu, makanan untuk santapan harian dihidangkan di atas Pahar (pn) menandakan tamu tersebut berasal dari kalangan bangsawan (pt). Hal tersebut dikaitkan dengan makna dikenakannya talam berkaki oleh keturunan Keratuan Darah Putih yang berada dalam formasi paling depan menghadap penonton pada Tari Kiamat. Seperti yang dikatakan oleh bapak Budiman Yakub selaku penasihat Keratuan Darah Putih dalam wawancaranya yaitu menaiki talam (pn) memiliki maksud ditinggikan satu tingkat, dihormati satu tingkat saja. ${ }^{13}$ Makna tersebut ialah memimpin satu tingkat lebih tinggi namun tetap pada kodratnya sebagai manusia untuk tidak dihormati melebihi satu tingkat dan saling menghargai (pt).

\section{H. Makna dan Simbol Tempat dan Waktu Pertunjukan Tari Kiamat}

Tempat pertunjukan dalam Tari Kiamat awalnya ialah di Lamban Balak (pn) yang

\footnotetext{
${ }^{13}$ Hasil wawancara Bapak Budiman Yakub dikediaman beliau Kuripan Lampung Selatan pada tanggal 18 Januari 2019.
} 
menandakan bahwa acara tersebut sakral sebagai rangkaian acara penutup yang sangat dihormati (pt). Namun mengingat pelestariannya tari ini dibolehkan untuk dilakukan di luar Lamban Balak, namun harus dengan keputusan pihak Keratuan Darah Putih. Waktu ditampilkannya Tari Kiamat sebagai tarian penutup pada saat subuh (pn) menyimbolkan lahirnya umat manusia (pt). Lahirnya umat manusia sama halnya dengan lahirnya kembali suatu kehidupan yang kembali suci, kembali bersih, kembali bersemangat dalam menjalani kehidupan ke arah yang lebih baik lagi (pt).

\section{PENUTUP}

Pembahasan di atas memberikan kesimpulan terhadap analisis makna terhadap simbol-simbol yang muncul di dalam Tari Kiamat pada masyarakat Keratuan Darah Putih. Simbol yang nampak secara visual dalam bentuk penyajian Tari Kiamat memiliki makna-makna yang memiliki relasi terhadap kepemimpinan dalam sistem kemasyarakatan Keratuan Darah Putih. Secara umum, simbol warna yang terlihat secara visual yakni merah, putih, dan emas (pn) melambangkan kehidupan masyarakat yang mementingkan kehidupan bersama, gotong royong, berani dalam bertindak untuk mengeratkan tali persaudaraan demi terwujudnya kehidupan ke arah yang lebih baik (pt).

Pernyataan tersebut dikuatkan dengan adanya simbol-simbol lain yang muncul dari pola lantai, gerak, dan iringan (pn) yang melambangkan sistem kepemimpinan dalam masyarakat Keratuan Darah Putih. Gerakan yang mengalun diiringi dengan irama perpaduan instrument musik yang monoton melambangkan sifat konsisten dalam menjaga suatu nilai dan adat yang ada pada masyarakat Keratuan Darah Putih. Posisi penari sebagai ratu yang menaiki talam/pahar berkaki diikuti penari lainnya yang berada di belakang (pn) melambangkan rasa hormat, mengikuti contoh kebaikan yang dilakukan oleh pemimpin, saling mengayomi, dan menjaga satu sama lain antara pemimpin dengan masyarakatnya (pt).

Tari Kiamat yang berasal dari kata Qiyam yang berarti tegak atau bangkit (pn) dapat ditarik relasi makna dari arti kata "kiamat" yang sesungguhnya yakni kebangkitan. Kata kebangkitan bermula dari kata dasar bangkit yang dapat dianalogikan sebagai berikut:

Suatu hal persoalan dapat dikatakan bangkit apabila ada sesuatu yang berlawanan dari kata bangkit seperti, jatuh=bangun (bangkit), lemah=kuat (bangkit) sehingga kata kebangkitan berdasar pada sesuatu yang mendukung, mendorong, menguatkan. Perumpamaan tersebut dapat dikaitkan dengan adanya Tari Kiamat yang ditampilkan pada saat penutup acara ruwah/syukuran, bangkit dari rasa lelah, ucapan terima kasih atas semua kerja keras yang telah dilakukan selama proses hingga puncak acara ruwah adat pihak Keratuan Darah Putih (pt).

Hasil akhir keseluruhan analisis dalam Tari Kiamat menunjukan relasi yang kuat dalam masyarakat Keratuan Darah Putih yang berpedoman dengan Piil pesenggiri sama dengan pedoman hidup masyarakat Lampung pada umumnya. Tari Kiamat memiliki makna yang muncul dalam simbol-simbol yang dapat dilihat dari sakral dan agungnya tarian ini pada masyarakat Keratuan Darah Putih baik yang terlihat secara visual ataupun analogi. Pernyataan tersebut dapat dikaitkan dengan wujud Tari Kiamat yang sesungguhnya hanya ada dalam pernikahan keluarga Keratuan atau dapat dilihat dari keturunan anak laki-laki pertama pihak Keratuan Darah Putih. Hal tersebut menyebabkan kurun waktu dipentaskannya Tari Kiamat hanya terjadi 2030 tahun sekali dalam upacara perkawinan adat Keratuan Darah Putih. 


\section{DAFTAR SUMBER ACUAN}

\section{A. Sumber Tertulis}

Ahimsa-Putra, Heddy Shri. 2001. Strukturalisme LeviStrauss Mitos dan Karya Sastra. Yogyakarta: Galang Press.

Ali, Matius. 2011. Estetika: Pengantar Filsafat Seni. Tangerang: Sanggar Luxor.

Bahri, Syamsul, Destika Mulyasari. 2018. Kabupaten Lampung Selatan Dalam Angka 2018.BPS Kabupaten Lampung Selatan.

Budiman, Kris. 2011. Semiotika Visual: Konsep, Isu, dan problem ikonisitas. Yogyakarta: Jalasutra Anggota IKAPI.

Dana, I wayan. 2014. Melacak Akar Multikulturalisme di Indonesia Melalui Rajutan Kesenian. Yogyakarta: Cipta Media bekerjasama dengan ISI Yogyakarta.

Departemen Agama RI. 2007. Al-quran dan Terjemahnya. Bandung: PT Sygma Examedia Arkanleema.

Dinas Pariwisata Kebudayaan Lampung Selatan. 2015. Cerita Sejarah Lampung Selatan. Lampung.

Geertz, Clifford. 1974. The Interpretation of Cultures: Selected Essays, London, Hutchinson \& CO Publisher, Terjemahan oleh Francisco Budi Hardiman, 1992. Kebudayaan dan Agama. Yogyakarta: Kanisius.

Hadi, Y. Sumandiyo. 2018. Revitalisasi Tari Tradisional.Cipta Media: Yogyakarta.

Hersapandi. 2017. Metode Penelitian Tari. Yogyakarta: Badan Penerbit ISI: Yogyakarta.

Irianto, Agus Maladi. 2015. Interaksionisme Simbolik. Semarang: Gigih Pustaka Mandiri.

Liliweri, Alo. 2002. Makna Budaya Dalam Komunikasi Antarbudaya. Yogyakarta: PT LKiS Pelangi Aksara.

Littlejohn, Stephen W. 2011. Teori Komunikasi. Jakarta: Salemba Humanika.

Martiara, Rina. 2012. Nilai dan Norma Budaya Lampung Dalam Sudut Pandang Strukturalisme. Yogyakarta: Badan Penerbit ISI Yogyakarta.
Martiara, Rina. 2014. Cangget: Identitas Kultural Lampung Sebagai Bagian Dari Keragama Budaya Indonesia. Yogyakarta: Badan Penerbit ISI Yogyakarta.

Mustika, I Wayan. 2012. Tehnik Dasar Gerak Tari. Elex Media Komputindo.

Mustika, I Wayan. 2013. Tari Muli Siger. Bandar Lampung: Anugrah Utama Raharja (AURA).

Soedarsono. 1977. Tari-Tarian Indonesia 1. Jakarta: Proyek Pengembangan Media Kebudayaan, Ditjen Kebudayaan, Depdikbud.

Soedarsono. 2004. Pengantar Pengetahuan dan Komposisi Tari. Yogyakarta: ASTI.

Sudjiman, Panuti dan Aart Van Zoest. 1992. SerbaSerbi Semiotika. Jakarta: PT Gramedia Pustaka Utama.

Sugiyono. 2011. Metode Penelitian Kuantitatif, Kualitatif, dan R\&D. Bandung: Alfabeta.

Sulasman dan Setia Gumilar. 2013. Teori-Teori Kebudayaan dari teori hingga aplikasi. Bandung: CV Pustaka Setia.

Sumardjo, Jakob. 2006. Estetika Paradoks. Bandung: Sunan Ambu Press: STSI Bandung.

Sumaryono. 2011. Antropologi Tari Dalam Perspektif Indonesia. Badan Penerbit ISI Yogyakarta: Yogyakarta.

Spradley, James P. 1997. Metode Etnografi. Yogyakarta: PT Tiara Wacana Yogya.

Turner, Victor. 2011. From Ritual To Theatre: The Human Seriousness of Play, New York: PAJ Publication, Terj. St Hanggar Budi Prasetya. 1980. Dari Ritual ke Teater. Yogyakarta: DIPA ISI Yogyakarta.

Wulandari, Mustika. 2016. "Tari Kiamat Dalam Pendidikan Nonformal Di Sanggar Intan Desa Kuripan Kabupaten Lampung Selatan”. Skripsi guna memperoleh gelar Sarjana Strata 1 Pendidikan, Program Studi Seni Drama, Tari, dan Musik Universitas Lampung.

B. Narasumber

Budiman Yakub, 61 tahun, pengajar, tokoh adat selaku penasihat dan juru bicara Keratuan Darah Putih dengan gelar Raden Kesuma 
Yuda dikediamannya Kuripan, Lampung

Selatan pada tanggal 16 Januari 2019.

MustikaWulandari, 23 tahun, pengajar, tokoh adat selaku puteri keturunan Keratuan Darah Putih Kuripan, Lampung Selatan pada tanggal 16 Januari 2019

Ridwan, 52 tahun, PNS, selaku pelatih Tari Kiamat Sanggar Intan Kuripan di Taman Budaya Provinsi Lampung pada tanggal 20 juli 2018.

Yoga Pramana Aji, honorer Dinas Pariwisata dan Kebudayaan, tokoh adat dengan gelar Raden Mas Kesuma Ratu pada tanggal 8 Februari 2019.

\section{Webtografi}

http://www.lampost.co/berita-kisah-sang-ratudalam-tarian-kiamat11 Februari 2018

http://text-

id.123dok.com/document/oz13843q-tari-

kiamat-dalam-pendidikan-nonformal-di-

sanggar-intan-desa-kuripan-kabupaten-

lampung-selatan.html Mustika Wulandari

2016.

https://id.m.wikipedia.org/wiki/Marga_di_Lampung

http://yusack.blogspot.com/2010/11/psikologi-

warna $12 . h t m l ?=1$

https://norisanto.com/arti-dan-makna-simbol-hewan/

\section{Diskografi}

https://youtu.be/y-yu1kP9dvl (TariKiamat

Lampung Care Unila) diunduh pada tanggal 16 Januari 2018

https://youtu.be/dovvc_zZ30

(TARI

KIAMAT Dari Keratuan Darah Putih Desa

Kuripan kec. Penengahan lam-sel). Dipublikasikan tanggal 21 Mei 2018.

https://youtu.be/AXgWx hF 00

(TARI
Koleksi pribadi latihan Tari Kiamat Sanggar Intan Kuripan pada tanggal 03 maret 2018

KIAMAT-KERATUAN DARAH PUTIH) 